\title{
Local government autonomy and development of localities in Nigeria: issues, problems and suggestions
}

\author{
Joseph Imhanlahimi ${ }^{1}$ \\ Ambrose Alli University, Ekpoma, Nigeria \\ imhanje@yahoo.com
}

\begin{abstract}
The topical issue of local government (LG) autonomy in Nigeria in relation to the development of the localities, the raison d'etre of LGs, has been examined in this paper. Proceeding from theoretical framework and conceptualizations for clearer understanding, the paper discusses some dominant autonomy issues. These include representative LGs, the size of LGs, revenue, and personnel. The paper found that inadequate handling of virtually all the above issues has posed some challenges for LGs' developmental efforts in the localities. Inadequate autonomy has been found to be the independent variable in the challenges. Other challenges include inadequate finances, weak intergovernmental relations, fledging democracy and grand corruption. These must be adequately tackled for LGs to make more positive impact in the localities. Some pertinent recommendations are as follows. LGs need adequate autonomy, hard work rather than verbal institutionalization, democratic consolidation, reduced corruption, increased discipline and application of the rule of law.
\end{abstract}

Keywords: Local government autonomy, Nigeria - local government, Nigeria

\section{Introduction}

The definition of local government (LG) by the Nigerian Federal Government leaves one with no iota of doubt that it is largely both theoretically sound and service oriented to the people. It talks of representative councils with substantial control over local affairs, for the provision of services and implementation of projects in their areas, to complement the activities of both the State and Federal governments. The definition also amply recognizes the need for LG autonomy as the substantial control of local governments (LGs) is aimed at staff, institutional and financial matters, among others (Nigeria, 1976).

In addition to the above, the Nigerian Federal Government is one of the few governments in the world perhaps in addition to Brazil (Erero 1998) that have elevated LGs to a third tier of government. By so doing, the State governments do not exercise absolute controls over LGs. As we shall also observe later, there are many checks and balances that have been formulated by the Nigerian Federal Government, to facilitate the effective operations of the local government councils (LGCs). Some of such checks and balances are guaranteed existence of LGs in section 7 of the 1999 Constitution, financial allocation from the Federation account and involvement of LGs in economic planning of the State governments (Nigeria 1999a).

In spite of the said establishment of the twin relationship of LG autonomy and the service and development rationale of the LGs in Nigeria, the latter, as shall be shown below, are full of stories of woes about their problems. These are largely hinged on inadequate autonomy especially in vital areas such as staff and institutional management and development, as well as financial matters, etc. which greatly hinder their development efforts in their localities.

The above paradoxical situation is what this paper has examined, to find out the missing links between LG autonomy and the development of the localities in Nigeria. The missing links are important for identification. This is because as we have stated earlier, the encouraging documentary provisions on LG autonomy and the rationale for the LG system in Nigeria are hinged on the provision of services and development projects in the localities. Specifically, the paper carefully, critically and objectively examines operational definitions, resource allocations, and development and opinion of the people expressed through the print media about the impact of the LGs in their areas.

And of course, germane recommendations which emanate from the study are provided for the improvement of LG autonomy and the development of the localities.

Both the bench work and content analysis of the people's opinion expressed in the mass media are approaches that have been adopted in this paper. A careful, logical and rather detailed analysis of existing general literature and government publications on LG autonomy and development of their localities constitutes part of the bench work. The government publications include those of the Federal Office of Statistics (now renamed National Bureau of Statistics NBS), and annual reports of the Central Bank of Nigeria (CBN). Also utilized are some performance indicators of LGs. In addition, content analysis of the opinions of the people on LGs' performance in the localities was also undertaken.

I. Joseph Imhanlahimi, PhD, is a Lecturer in the Department of Curriculum and Instruction, Faculty of Education, Ambrose Alli University, Ekpoma, Nigeria

Inkanyiso, Jnl Hum \& Soc Sci 20I I, 3(I) 
Structurally, this paper is presented as follows: the first section contains the introductory, problem statement, and methodological preliminaries. Section two provides the theoretical framework and conceptual issues. These are followed in section three by an examination of dominant issues, such as different types of resources, provided and generated by the LGs themselves for deployment. Section four discusses LGs' development efforts in the localities, and the attendant problems are presented in section five. The recommendations for improvement in the promotion of LG autonomy to facilitate adequate or acceptable level of development of the localities in Nigeria follow in section six.

\section{Theoretical and conceptual issues}

The theory which informs our discussion of LG autonomy in Nigeria is the general systems theory. It is a theory that has been contributed to by a number of writers, such as Almond (1960); Easton (1965); Adamolekun (1983) and Offiong (1996). A synthesis of the definitions of a system given by various writers, some of whom are listed above, can be stated as follows. It is a phenomenon of whatever type, including physical, biological, social, political, etc., which is an organized whole with identifiable, interrelated structures delineating it from the environment (supra system) in which it is located and with which it interacts, processing the inputs from it into outputs for it.

The general systems theory seeks to argue that every system, including political system, has subsystems which make up the entire system. They are assigned functions and provided with enabling empowerment, including resources, appropriate authority, etc. to enable them discharge their responsibilities optimally. Or as Ibeanu(2000) states, from a structural-functionalist perspective, there is harmony where existing social structures perform their functions adequately. Where this is the case, there is said to be homeostasis (stability) in the political system. On the other hand, instability reigns in the political system where the contrary is the case and the subsystems and entire system are also unable to function optimally.

Input and output analysis of a political system is very important. A political system is said to obtain its inputs (demands, supports, liberty or autonomy, cooperation, criticisms, resources, information, direct labour, etc.) from the people (Adamolekun 1983., Imhanlahimhin 2000). It may be pointed out that some of these inputs, such as liberty or autonomy, cooperation, and direct labour, were not specified in the original or earlier analysis of the general systems theory, but they are considered important for this paper. These inputs are what the subsystems employ to discharge their responsibilities, so that the political system can send out its outputs into the environment and obtain further inputs for its operations.

Applying this brief exposition of the political systems analysis to the Nigerian LG system, the LGs in the country constitute the subsystems. They must be well handled in terms of being fed with adequate inputs, as provided for in the constitution (e.g. Nigeria 1999a), so that they can contribute appropriately to the optimality of the Nigerian political system, as well as its homeostasis. If the reverse is the case, that is, if the LGs do not have the required inputs to operate, two important things may happen. First is that there might be instability and the second is that there might be discontent amongst the citizenry. The two are intertwined,

It is therefore very useful to realize the importance of the systems theory in the handling of LG autonomy in Nigeria. This means the realization of the sub-systemic nature of LGs which are an integral part of the overall Nigerian political system. They have their assigned responsibilities to perform to the benefit of the people, not as appendages of either the Federal or State Governments. Failure to treat the LGs as such could send frustration through their veins, disenchantment and inability to perform and hence dissatisfaction amongst the populace.

For space constraint, we cannot render the various definitions of LG offered by scholars and writers. What we observe in many of them is that they contain words or phrases that tend to give the impression that local administration and local government are synonymous. For example, the United Nations cited in Ola and Tonwe (2005) admits of local selection of persons (instead of only election) to constitute local government councils (LGCs). The Nigerian government's definition contains 'devolution of functions' (which borders on administrative relationship with a higher authority) to the councils (Nigeria, 1976: para. 3)

One of the most acceptable definitions of LG to us is offered by Mawhood (1993: VII \& 2). He defines LGs as bodies ... separated by law ... (and have) local representatives (and) ... formal power to decide on a range of public matters .... Their right to make decisions is entrenched by the law and can only be altered by a new legislation. They have resources, which subject to the stated limits, are spent and invested at their discretion.

Our only small observation in Mawhood's definition is the failure to specify the mode of local representation in LG councils, that is, whether by selection or election. A definition of LG that is very acceptable to us is offered by Imhanlahimi and Ikeanyibe (2009:82). For them, a LG has a defined area and a popularly elected democratic council. It has formal powers derived from the laws or constitution of the land, to decide on a range of public matters in consultation with other stakeholders, including traditional rulers, for the locality. The formal powers can only be altered by a subsequent 
legislation or constitutional amendment. The LG has personnel, financial and other resources, from whatever sources, which are deployed, spent and invested at its own discretion for the execution of legally or constitutionally assigned and mutually agreed functions for the overt development of the area.

This definition captures the essential characteristics in LG that we are interested in, in this paper.

These include elective representation, legally or constitutionally recognized functions and adequate powers over personnel and finances, subject to the environment of autonomy.

The LG autonomy we have in mind is the one that is adequate, not absolute, for the LGCs to perform their responsibilities optimally. Two types of autonomy appear to have been canvassed in the literature: absolute and adequate/relative. Chaturvedi (2006:19) represents the absolutist school as he states that 'in local autonomy, the local body has financial and management autonomy' to decide and determine its own course of action. There is no rider whatsoever. Mawhood (1993:8) straddles both schools because he insists that there is relative separation of central and local spheres of government on the one hand. On the other hand, he says that the central government should only 'monitor the activities of local authorities without intruding into their domain'

For these writers, autonomy for the LGs in Nigeria, as indeed in all the emerging or less developed countries (LDCs) of the world, should be relative, not absolute. The rationale for this is that there is in fact one territory that is being developed by all the three tiers of government in, for example, Brazil, Ethiopia, and Nigeria. The resources for development in the LDCs are very scarce and should therefore be cooperatively managed for optimality, in the interest of the localities. Indeed, it has been gradually recognized that politics - administration cooperation in the LDCs, for example, Nigeria, appears to be healthier than the dichotomy which Wilson (1887) had stressed. And it has also been gradually agreed that active, competitive and cooperative intergovernmental relations (IGRs) (Erero 1998) in the LDCs, for example, Nigeria and Brazil, seem healthier than Wheare's (1946) absolute separation of responsibilities and powers (Mackenzie 1967; Idahosa and Igbineweka 1996). This means that the atmosphere of cooperative competition denoted by adequate autonomy is healthier than the one of conflictual competition represented by absolute autonomy.

We therefore define the relative/adequate autonomy that LGs in the LDCs, Nigeria inclusive, should obtain to enable them perform their functions optimally in the people's interests. It is freedom to the LGs to exercise authority within the confines of the law or constitution. This is to enable them to discharge legally or constitutionally assigned responsibilities satisfactorily, but without undue interference or restraint from within or higher authority. This definition argues for adequate autonomy for LGs within the law for the purpose of performance, which actually guarantees it. Without performance, the law or constitution may not be able to guarantee even adequate autonomy for LGs as the people yearn for development. Autonomy operated within a democracy must be limited as indeed democracy limits the use of power.

\section{Dominant issues in LG autonomy in Nigeria}

The important issues in LG autonomy in Nigeria started to emerge with the 1976 far reaching LG reforms. Before 1976, local administration, rather than LG, could be said to have existed in Nigeria. This is because from the colonial era up to 1975, administration at the local level was an appendage of the Regional and later State governments. This was in spite of previous reforms by the Regional governments at the local level in the 1950s and in post-independence era by the State governments up to 1975 (see, for example, Gboyega 1993; Ola 1984; Ola and Tonwe 2005; and Ikelegbe 2005).

It was from the 1976 LG reforms that some dominant issues in LG autonomy could be easily appreciated. These include the setting up of representative councils, determination of population size of LGs, direct allocation of funds to LGs and review of personnel administration. We briefly discuss each of these below.

Representative LGs. - The guidelines on the 1976 LG reforms started the autonomy of LGCs when they stated that 'membership of Local Government Councils should be predominantly elected either by direct or indirect elections from local communities ...' (Nigeria 1976; para. 25). The fledging autonomy of LGs was driven into the 1979, 1989 and 1999 Nigerian Constitutions. In section 7 of each of the constitutions, there is a clause that states 'the system of local government by democratically elected local government is under this constitution guaranteed'. The constitution extended this guarantee in section 8 to 'the establishment, structure, composition, finance and functions of such councils; by directing the States to enact a law to the above effects. And the State governments have been doing so through the enactment and amendment of LG laws since year 2000, even though scant respect has been extended to this and other enactments on $L G s$ as we shall observe below.

The importance of democratically elected LGs could only be under emphasized (Ola 1996). Our conceptualization of democracy also supports this view. In terms of autonomy of LGs, democratically elected LGCs simply means that the councillors would no longer be the candidates of State governments as was the case in the past. It further means that councillors would be sure to serve out their terms without fear or favour, except a councillor acted unlawfully.

Inkanyiso, Jnl Hum \& Soc Sci 20I I, 3(I) 
Size of LG - The 1976 LG reform guidelines also contained issues aimed at promoting the autonomy of Nigerian LGs. These included ensuring that LGs can execute 'all types of functions reasonably economically ... by having population of between 150,000 and 800,000 ... limits (which) may be varied in exceptional geographical circumstances (Nigeria 1976: para. 8).

This well intentioned policy has not been abrogated since then, although the practice as Table I shows has been greatly compromised. The rationale for the maximum population size policy derives from the general minimum population figure or strength that can support a viable community. Promotion of viable community spans issues such as dynamic social, economic, political and cultural matters. These are more adequately or satisfactorily handled with minimum population in the community. With little or small population, the dynamic nature of the above issues is greatly reduced.

Table I shows that contrary to the well informed intention of the Nigerian government on minimum population for LGs, out of 774 LGs in the country, following the 2006 census, 105 (13.57\%) LGs have less than 100,000 population each. 242 (31.27\%) LGs have less than I50,000 population each. This means that 347 (44.84\%) LGs have less than the minimum 150,000 population size to carry out 'all types of functions reasonably economically ...' (Nigeria 1976: para. 8). 427 (55.16\%) LGs have 150,000 or above population each. The 347 (44.84\%) LGs that have less than the minimum of 150,000 population constitute a large and rather disturbing number or percentage. Hence Gboyega (1993) described the situation as fragmentation of LGs.

It is interesting to observe that in the less politicized period of the 1970s, when mineral oil had not made Nigeria a rather monolithic economy, a good number of LGs had the minimum 150,000 population. For example, only 35 (II.63\%) LGs had below 150,000 population out of 30 I LGs in 1976. 252 (83.72\%) LGs had a population of between 150,000 and 800,000 each, while three $(0.99 \%)$ had over 800,000 population (Ola and Tonwe 2005 ). There was no information in respect of II (3.65\%) LGs. This means that 255 (84.7I\%) LGs had a population of I50,000 or above each in the 1970s when revenue derivation principle still had a little meaning in the revenue sharing formula of the country.

With little population size against what had been considered a reasonably supportive population during the less politicized period of the 1970s, we now tend to have what may be described as cap-in-hand LGs. They can hardly depend on their population but on external funding as we shall observe later. The implication is that LG autonomy in this regard has been greatly whittled down.

LG finances - It is in this issue that the Nigerian government seems to have done quite a lot to promote LG autonomy, no doubt, for the purpose of their greater development impact in the localities. The government has contributed to the promotion of LGs' financial autonomy in two basic ways. First is through direct financial allocations to them as Table 2 shows. And second is through constitutional provisions for many of their revenue sources as enshrined in, for example, sections 149 and 162 of the 1999 constitution.

The literature on this matter (see, e.g., Aghayere 199I; Aghayere 2008; Nchuchukwe 2003; Ikelegbe 2005; Imhanlahimi and Ikeanyibe 2009) and Table 2 agree that the LGs have not been doing enough to protect their financial autonomy. Table 2 shows that LGs have been receiving the bulk of their funds from external sources, that is, the federal government. For example, between 1993 and 2006, the Nigerian federal government's finances to the LGs have ranged between 88.8 per cent in 1995 and 96 per cent in 2006. From 1999, the federal government's financial allocations to the LGs have not been below 91 per cent.

On the other hand, the LGs have contributed paltry sums between 1993 and 2006 as their internally generated revenue (IGR) to their financial needs. These have ranged from 3.5 per cent in 2006 to 8.7 per cent in 1995. Table 2 also actually shows that LGs' IGR in Nigeria has been going down since 200 I, ranging between 3.5 and 5.6 per cent as against 5.I and 8.7 per cent between 1993 and 1999. This is an average of 5.83 per cent which is even higher than the average of about 4.18 per cent that Aghayere (1997) found in respect of LGs in Edo State, which much emphasizes low internal revenue generation by LGs.

The State governments as another external revenue source have not been very helpful to the LGs as their contributions have ranged between 0.3 and 0.9 per cent between 1993 and 2006. More disturbing, as Ola and Towe (2005) and Aghayere (2008)have reported, is that the State governments interfere with federal government's financial allocations to the LGs. This is addition to the said default in State governments' statutory contribution of 10 per cent of their IGR to the LGs. 
Table I Population base of 774 LGs in Nigeria, 2007

\begin{tabular}{|c|c|c|c|c|c|}
\hline States & $\begin{array}{l}\text { No. of LGs below } \\
100,000 \text { population } \\
\text { (II) }\end{array}$ & $\begin{array}{l}\text { No. of LGs below } \\
\text { I50,000 population } \\
\text { (III) }\end{array}$ & $\begin{array}{l}\text { Sub-total } \\
\text { (ii-iii) } \\
\text { (IV) }\end{array}$ & $\begin{array}{l}\text { No. of LGs with } 150,000 \\
\text { or above population } \\
\text { (V) }\end{array}$ & $\begin{array}{c}\text { Total No. of LGs } \\
\text { (VI) }\end{array}$ \\
\hline Abia & 3 & 5 & 8 & 9 & 17 \\
\hline Adamawa & 2 & 8 & 10 & 11 & 21 \\
\hline Akwa Ibom & 9 & 16 & 25 & 6 & 31 \\
\hline Anambra & 1 & 4 & 5 & 16 & 21 \\
\hline Bauchi & 2 & 3 & 5 & 15 & 20 \\
\hline Bayelsa & - & 1 & 1 & 7 & 8 \\
\hline Benue & 3 & 3 & 6 & 17 & 23 \\
\hline Borno & 7 & 10 & 17 & 10 & 27 \\
\hline Cross River & 2 & 3 & 5 & 13 & 18 \\
\hline Delta & 2 & 12 & 14 & 11 & 25 \\
\hline Ebonyi & - & 5 & 5 & 8 & 13 \\
\hline Edo & 3 & 6 & 9 & 9 & 18 \\
\hline Ekiti & 3 & 7 & 10 & 6 & 16 \\
\hline Enugu & - & 7 & 7 & 10 & 17 \\
\hline Gombe & - & 2 & 2 & 9 & 11 \\
\hline Imo & 3 & 13 & 16 & 11 & 27 \\
\hline Jigawa & 4 & 10 & 14 & 13 & 27 \\
\hline Kaduna & - & 4 & 4 & 19 & 23 \\
\hline Kano & 1 & 11 & 12 & 32 & 44 \\
\hline Katsina & 1 & 10 & 11 & 23 & 34 \\
\hline Kebbi & 4 & 6 & 10 & 11 & 21 \\
\hline Kogi & 3 & 10 & 13 & 8 & 21 \\
\hline Kwara & 5 & 5 & 10 & 6 & 16 \\
\hline Lagos & - & 2 & 2 & 18 & 20 \\
\hline Nassarawa & 3 & 7 & 10 & 3 & 13 \\
\hline Niger & 4 & 6 & 10 & 15 & 25 \\
\hline Ogun & 5 & 4 & 9 & 11 & 20 \\
\hline Ondo & 2 & 4 & 6 & 12 & 18 \\
\hline Osun & II & 13 & 24 & 6 & 30 \\
\hline Оуо & 2 & 16 & 18 & 15 & 33 \\
\hline Plateau & 2 & 4 & 6 & 11 & 17 \\
\hline Rivers & 1 & 3 & 4 & 19 & 23 \\
\hline Sokoto & 2 & 8 & 10 & 13 & 23 \\
\hline Taraba & 8 & 4 & 12 & 4 & 16 \\
\hline Yobe & 4 & 8 & 12 & 5 & 17 \\
\hline Zamfara & - & 2 & 2 & 12 & 14 \\
\hline FCT* & 3 & - & 3 & 3 & 6 \\
\hline Total & 105 (I3.57\%) & 242 (3I.27\%) & 347 (44.84\%) & 427 (55.16\%) & $774(100 \%)$ \\
\hline
\end{tabular}

Source: Calculated from Nigeria (2007)

* FCT = Federal Capital Territory. It has Area Councils which are treated like LGs. 
Table 2 Local Governments' finances, 1993-2006

\begin{tabular}{lccccccccc}
\hline \multicolumn{1}{c}{ Sources } & $\mathbf{1 9 9 3}$ & $\mathbf{1 9 9 5}$ & $\mathbf{1 9 9 7}$ & $\mathbf{1 9 9 9}$ & $\mathbf{2 0 0 1}$ & $\mathbf{2 0 0 3}$ & $\mathbf{2 0 0 5}$ & $\mathbf{2 0 0 6}$ \\
\hline Fed. Rev. All. & 93.4 & 88.8 & 89.5 & 91.5 & 95.5 & 93.8 & 95.3 & 96.0 \\
\hline State Rev. All. & 0.3 & 0.6 & 0.7 & 0.4 & 0.9 & 0.6 & 0.5 & 0.5 \\
\hline LGs Inter. Rev. & 5.1 & 8.7 & 8.3 & 7.9 & 3.5 & 5.6 & 4.1 & 3.5 \\
\hline Other funds & 1.2 & 2.0 & 1.5 & 0.2 & 0.1 & 0.0 & 0.1 & 0.0 \\
\hline Total & 100.0 & 100.0 & 100.0 & 100.0 & 100.0 & 100.0 & 100.0 & 100.0 \\
\hline
\end{tabular}

Source: Imhanlahimi and Ikeanyibe ( 2009).

Key: Fed. Rev. Allo. - Federal Revenue Allocation

State Rev. Allo. - States Revenue Allocation.

LGs Inter. Rev. _ LGs Internally Generated Revenue (IGR).

Perhaps more important at this juncture is a consideration of the adequacy of the total revenue profile of LGs, from all sources, for their operations. The literature (e.g. Nchuchukwe 2003; lkelegbe 2005 and Aghayere 2008) is not agreed that LGs obtain adequate revenue for their operations. However, as lkelegbe (2005:54), for example, puts it, there is 'tremendous strengthening of local government funding, structuring, autonomy and democratization ....' But the use to which the LGs have put their funds will be instructive later, but for now we consider LGs' autonomy in personnel matters.

LGs' Personnel - Personnel administration is on area in which LGs' autonomy in Nigeria seems weakest. It is one area that is not covered by any constitutional or legal, but administrative, provision. This perhaps accounts for why the State governments through their Local Government Service Commissions (LGSCs), all over the country, claim monopoly of personnel matters in LG administration as we shall observe below. The 1976 guidelines on LG reforms had only stated mildly that LGs shall have 'substantial control over local affairs and staff ...' (Nigeria 1976: para. 3).

Two positions were canvassed on the personnel administration powers of LGs. First is for LGs to eventually exercise determinant powers or substantial control as stated above. And second is for LGs to work under the superintendence of the LGSCs of the various State governments. The second option has been the choice of the LGSCs who have been reluctant to move over to the first option (Gboyega 1993). They, in fact, overtly claim that all LGs' personnel are under the administration of the LGSCs. For example, Edo State LGSC stated in one annual report that it has responsibility 'to appoint, post, promote and discipline employees of the Local Government on salary grade level $0 \mathrm{I}$ and above .... (But) aggrieved officers on grade level 07 and above shall have the right to appeal to the Governor' (Edo State 2005: I-2). The LGSCs also undertake LGs' staff training. It is largely a situation in which the end users of personnel have little say in their administration. It is antithetical to modern personnel administration process in which the end users are now active participants.

What obtains in one State applies in virtually all other States with respect to LG personnel, especially by virtue of the meetings of the LGSCs all over the country. Also the LGSCs exchange their annual reports, so as to know what others are doing. To make the matter brief, the LGSCs with the tacit connivance of the State governments have put personnel administration squarely under their control. In spite of the merits of this option, including uniformity and reduced politicization in personnel administration, the autonomy of the LGs in the matter is greatly limited and it can affect their development impact in their localities.

\section{Local Government autonomy and development of local areas}

The areas in question in this discussion are those of each LG which are therefore to be found in both the urban and rural sectors, but predominantly in the latter. The issue of interest to this paper here is an overview of how LG autonomy or the lack of it has impacted on the development of the locality, in particular the rural localities.

Quite some work has been done on the development of the rural areas by the Nigerian LGs. The critical aspects in the local or rural development issue include availability of network of earth or tarred roads, electricity supply, pipe borne water, schools, health centres or cottage hospitals, mass transit system, telecommunication, political development, etc. The literature on LGs' efforts to develop the local areas in Nigeria shows that the respective LGs have been showing varying concerns of development efforts to make positive impact on the lives of the local people. The efforts may have been rather low, but all over the country, LGs have tried in varying degrees to meet the needs and aspirations of their localities in three main approaches. 
First, some LGs have established Development Area Councils or Committees, so as to take governance closer to the people. Such LGs include those in Lagos, Yobe, Bauchi (Yobe State 2003., Bauchi State 2004). The second approach adopted by some LGs is the appointment of Ward Committees to handle or supervise some development projects which are being executed directly by the LGs or executed by them on behalf of the Federal or State governments. The third approach is the use of community development associations (CDAs) (Akoptor 1995) or Town Improvement Unions as critical agents in community development even though they have been less utilized (lkelegbe 2005). There are also extension workers who are located in the third category. They are used by LGs especially for agricultural purposes. They move within and between ward or village areas educating farmers, advising and assisting them on the application of newly introduced seedlings, the use of insecticides and irrigation farming. Irrigation farming is predominant in many LGs in the Northern States of Nigeria where Fadama farming has been largely successful. That is, taking farming to the local farmers through bio-technology of improved seedlings, insecticides, extension services, irrigation and micro credit schemes. And the LGs have been uncompromising in asking for democratically elected LGs as part of their holistic development efforts.

Using any of the approaches, the LGs, subject to the financial, personnel and other resource autonomy granted to them, have been rehabilitating earth roads, culverts, local or community markets, renovating school buildings and erecting new ones. They have been establishing cottage hospitals or health centres, refurbishing pipe borne water structures, sinking or refurbishing bore holes, executing rural electrification projects, providing improved seedlings with respect to yams, cassava in particular, maize, oranges, coconut, tomatoes, rice, millet, etc. They have also been promoting political participation and governance.

As already stated, these projects are executed in different localities having regard to the priorities of the people. The number of projects executed varies from one LG to another. But the literature, some interviews conducted by these writers and Table 3 show that the impact of LGs on the localities is rather sparse or lean and the people of each locality cannot but be full of complaints of inadequacies and dissatisfaction in the development strides of the LGs (Aghayere 2008; Omoruyi 1995; Mukoro 200I; Ikelegbe 2005).

Table 3 LGs' recurrent expenditure in relation to capital expenditure (per cent) in Nigeria, $1993-2006$

\begin{tabular}{lcl}
\hline Year & Recurrent exp. & Capital exp. \\
\hline 1993 & 71.8 & 28.2 \\
\hline 1994 & 77.9 & 22.1 \\
\hline 1995 & 72.8 & 27.2 \\
\hline 1996 & 72.3 & 27.7 \\
\hline 1997 & 72.5 & 27.5 \\
\hline 1998 & 58.6 & 41.4 \\
\hline 1999 & 68.9 & 31.1 \\
\hline 2000 & 61.0 & 39.0 \\
\hline 2001 & 71.6 & 28.4 \\
\hline 2002 & 73.4 & 26.6 \\
\hline 2003 & 58.5 & 41.5 \\
\hline 2004 & 64.1 & 35.9 \\
\hline 2005 & 63.7 & 36.3 \\
\hline 2006 & 59.8 & 40.2 \\
\hline 5015 & $2006)$ &
\end{tabular}

Source: Calculated from Nigeria (1999b, 200I, 2003, 2006).

Table 3 shows that except in 1998, 2003 and 2006 when the recurrent expenditure took between 58.6 and 59.8 per cent respectively, all the other years gulped between 61.0 and 77.9 per cent respectively. This left the capital expenditure during the period at between 22.I per cent and 41.5 per cent per year, or an average of 32.4 per cent during the period.

A plausible explanation for the rather acceptable capital expenditure situation in 2003 is that the military government led by General Abdulsalami Abubakar demonstrated a strong intention to hand over political power to a democratically elected government in 1999. The government was taken seriously by all and sundry. All levels of government, including Inkanyiso, Jnl Hum \& Soc Sci 20I I, 3(I) 
the government parastatals like the universities, seemed to have informally agree not to engage in any act that could precipitate a renege on the federal government's promise to hand over power to a democratically elected government in the country.

The plausible explanation for the 2003 situation could have been the Federal and State elections held in 2003. As for 2006 the Federal government's disciplinary machineries and measures, with special reference to the activities of the Economic and Financial Crimes Commission (EFCC) established in 2004, became tougher on corruption in government in the second half of 2005 and much more so in 2006. Public officers at all levels of government became a little more careful. The EFCC made a number of arrests and prosecutions and also made many threats of possible arrests and prosecution of serving Governors at the end of their tenure. Some citizens and the Nigerian press in particular engineered the EFCC to extend search lights to the LGs. All these tended to put the nerves of all government functionaries, including LGs, on edge. This perhaps partly explains why the LGs had to plough more funds into capital expenditure in 2006, thus bridging the gap between it and recurrent expenditure and no doubt making a little more impact on the ground too.

Of course, with the above information and situation, little impact could only have been made by the LGs in the localities with such low capital expenditure and little respect and shaky autonomy being the dividends for LGs. It should be possible for the LGs to sustain the capital expenditure of 1998, 2003 and 2006, by shedding some of their recurrent expenditure in the spirit of the liberalization, commercialization and privatization policy, due process, transparency and accountability "war" efforts being waged by the Nigerian government. These initiatives could result in more revenue for the development of the LG areas and hence more respect and autonomy for the LGs in Nigeria.

There is a dearth of published data by the appropriate institutions (e.g., Federal Office of Statistics now renamed National Bureau of Statistics, and the Central Bank of Nigeria - CBN) on LGs' development efforts in the localities. Stolpher (1966) and Yesufu (1996) are among other writers who have documented the dearth of data for research in Nigeria as worrisome. So there is lean statistical evidence to argue about the development efforts of the LGs in the localities in Nigeria. One of such evidence is indicated in Table 4. It presents the establishment of health facilities between 1987 - 1991, which shows that the LGs owned between 6,679 and 7,412 of such facilities during the period. The provision of such facilities is a primary responsibility of LGs.

Table 4 Ownership of health establishments in Nigeria, |987-199|

\begin{tabular}{lccccc}
\hline PROVIDERS & 1987 & 1988 & 1989 & 1990 & 1991 \\
\hline Fed. Govt. & 157 & 201 & 205 & 204 & 205 \\
\hline State Govt. & 2,982 & 3,251 & 3,277 & 3,353 & 3,355 \\
\hline LGs & 6,679 & 7,087 & 7,149 & 7,412 & 7,267 \\
\hline Private Owners & 1,905 & 2,058 & 2,058 & 2,295 & 2,295 \\
\hline Community & - & - & - & - & 140 \\
\hline Christian Missions & - & - & - & - & 601 \\
\hline Total & 12,531 & 13,427 & 13,345 & 14,103 & 13,872 \\
\hline
\end{tabular}

Source: Nigeria (1999b)

With 30 I LGs in existence by 1987, Table 4 shows that each LG provided only an average of 22 health establishments. In 1984, with 449 LGs in the country, each LG could provide only an average of 16 health establishments. With 589 LGs in existence in 1991, each LG owned only an average of 12 health establishments. This trend tends to illustrate the declining, poor development performance of the LGs which has continued to be the lot of their areas. On the other hand, with 21 state governments in existence in 1987, each state government owned an average of I42 health facilities, In I99I, there were 30 state governments and each owned an average of 112 health facilities. With respect to sheer number, what each LG could provide was rather very small evidence of development impact in the health sector.

Our concern in the section on LG autonomy and development of the localities in this paper, is to try and provide some empirical evidence about LGs' development impact in the localities, as a basis for some objective assessment of their performance. And because of the said dearth of data, we did some content analysis of some newspapers in Nigeria to determine people's feelings about the LGs' development efforts in the localities. The analysis is presented in Table 5.

The approach to the content analysis was simple. The various newspapers published between 2003 and 2007, that were available to these writers in the University of Benin Library, Nigeria, and in their homes, were content analyzed. 
The copies analyzed numbered 645. The purpose was to determine people's feelings as reported by the newspapers about the development impact of the LGs in the localities. People's feelings were differentiated broadly into two: praises and criticisms. Praises were operationalized or identified in the newspapers by words of praise used by the communities. Pictures of jubilations about LGs' activities, recounting of development activities of LGs in the newspapers, offering of direct free labour to assist LGs, and exercise of vigilance, especially at night, over LGs' facilities provided for the communities were also admitted as praises. Donation of parcels of land, reportage on commencement of development projects, and partnerships by LGs were also accepted as praises. Issues bordering on criticisms of LGs were operationalized or identified as follows: critical statements of blame or failure of LGs and pictures of demonstrations against LGs. Petitions, appeals to higher authorities on LGs' activities, sack of LG staff and road blockades by communities to protect the roads they repaired as a result of the ineffectiveness of the LG's constituted part of the criticisms. Each praise or criticism was taken through a tally whose aggregate per newspaper is reported in Table 5.

Table 5 Content analysis of some newspapers about people's views of LGs' development efforts in Nigeria, 2003 - 2007.

\begin{tabular}{|c|c|c|c|c|}
\hline S/No & Newspaper & No. of copies analyzed & No. of praises & No. of criticisms \\
\hline I & Independent & 52 & 3 & 10 \\
\hline 2. & Mirror & 15 & - & 5 \\
\hline 3. & Nation & 49 & 3 & 8 \\
\hline 4. & Punch & 60 & 5 & 12 \\
\hline 5 & Sun & 35 & 4 & 10 \\
\hline 6 & The Comment & 19 & 1 & 4 \\
\hline 7 & The Guardian & 109 & 2 & 17 \\
\hline 8 & This Day & 85 & 4 & II \\
\hline 9 & Tribune & 66 & 2 & 18 \\
\hline \multirow[t]{2}{*}{10} & Vanguard & 155 & 6 & 32 \\
\hline & Total & 645 & 30 & 127 \\
\hline
\end{tabular}

Source: Content Analysis of Some Nigerian Newspapers (2003-2007).

The Table shows that a total of 645 newspapers were sampled. Out of the 157 views expressed on local governments developments efforts nationally, only 30 or about 19.1 per cent of the people's feelings were praises for the LGs in the period 2003-2007. The number of criticisms was 127 or about 80.9 percent. Although people's feelings apparently were less reported in the newspapers, it nevertheless shows that they were by far disappointed in LGs' development efforts in the localities. This evidence tends to support the general view in the literature about LGs' unsatisfactory development efforts in their areas in Nigeria (see for example, Mabogunje 1980; Mukoro 2001; Omoruyi 1995; Ikelegbe 2005. The LGs, no doubt, experience some challenges.

Local Government autonomy and development of localities: some challenges

Quite a number of challenges have confronted LGs in Nigeria, in their bid to utilize their autonomy in the task of developing the localities. These include structural, operational, financial, patron/godfather pressure, unstable democracy and corruption Since they have been discussed in sections of this paper, they are presented briefly below.

Worried by the poor performance of the LGs, in spite of their empowerment through what lkelegbe (2005: 48) called 'increasing autonomy' since the 1976 LG reforms, the government set up the Dasuki Committee in I984. Its report expressed confidence in government's structural, financial and personnel arrangements for the LGs, among other matters. It however noted that the problems of the LGs were basically operational, 'arising directly from the behaviour and attitudes of the persons who operated the system' (Nigeria 1987: 120). Yet there is quite some agreement in the literature that LGs in Nigeria encounter all the above problems.

Structural - Structurally, Nigerian LGs encounter some kinds of inferior recognition by the Federal and State governments. It appears that LGs, by virtue of the recognition of a federation as being generally governed by the Central and State governments, are barely treated as a tier of government in Nigeria. Thus, in spite of the legal and constitutional provisions, LGs have been scrapped by both democratic and military regimes. The apparent structural inferiority of the LGs vis - a - vis the Federal and State governments, in spite of constitutional provisions, is a reality of disturbing Inkanyiso, Jnl Hum \& Soc Sci 20I I, 3(I) 
importance. These belittling attitudinal relationships of the higher level governments to the LGs actually, to a degree, erode LGs' autonomy. Interactions are bound to be skewed against the LGs.

Finance - LGs' financial problems appear to be more of their making as well as those of the State governments. Table 2 shows that LGs' finances are largely sourced from the federation account, which accounts for not less than 80 per cent. The State governments also contribute a little, below one per cent, to the LGs' financial needs. LGs have vast opportunities to increase their financial standing and hence autonomy through aggressive financial mobilization. But they hardly do, especially as they shy away from the collection of personal income tax from the citizenry and tenement rates. One of the reasons for the LGs' failure to collect such tax and rates appears to be the onerous task in the collection. Another reason seems to be the avoidance of harsh criticisms from the people who might pry much more closely into the deployment of the funds at the LGs' disposal. In other words, LGs realize that people are more critical of the government if they pay taxes and rates whose impact is very little on ground.

Another aspect of the financial matter which affects LGs' autonomy is the deployment of the funds at their disposal for development. Table 3 reveals that LGs, except in about three out of 14 years, $1993-2006$, spent vast proportion of their funds, on the average of 70 per cent, on recurrent expenditures. This left small proportion of the funds for capital projects which normally earn LGs praise and autonomy enhancement. As the popular saying goes, by thy fruits ye shall be known. LGs' fruits, that is development impact in the localities, have not made them to be well known.

Personnel Problems - The virtual centralization of the personnel administration function of the LGSCs all over the country is not only now old fashioned but out of mood. This is in spite of the said values of the LGSCs. Some of them are uniform personnel administration and less politicization. But the problems include depreciation of autonomy and structural appendage of LGs to the State governments. LGs are not allowed to exercise their discretion and undertake competitive personnel administration. In this scenario, LG staff could actually give more service loyalty to the LGSC than the LGs and get away with it, to the detriment of the localities.

Patron/godfather - The problem of patron/godfather in the LGs affects LGs' autonomy and hence the ability to make the desired development impact. The concept of political godfather is well known in Nigerian political scene (lkelegbe 2005; Imhanlahimi and Ikeanyibe 2009). A political patron/godfather is the sponsor of the political office holder, e.g., the LG Chairman. The latter has little autonomy before his patron/godfather. He takes dictates from the godfather and acts accordingly, especially if he wants a second term or peace in his office tenure. The sponsorship by the godfather is usually financially based, and so he has to recoup his expenditures from his political stooge. While the political office holder meets the demands of the godfather and his personal political interests, the funds left for development are lean. The localities suffer and LG autonomy is further questioned.

Democracy - Democratic consolidation process poses a problem for the LGs more than other governmental levels in Nigeria. This is because democracy has not taken firm roots due to the long years of military involvement in Nigerian politics. Its limiting positive effects are therefore hardly in place. Democracy is supposed to be rule-bound, respecting due process. The Federal and State governments seize the opportunity of fledging democracy to disregard the elective representative principle and constitutionally guaranteed existence of LGs.

At the least opportunity, for example, in 1980, 2002 and 2007, LGs have either been scrapped by higher level governments or had their democratic elections delayed. In their place, all manners of bodies such as development Committees, Sole Administrators and Caretaker Committees had been set up. Such policy reversal situations have had implications for the development of the localities, including loyalties to the State governments by the appointed functionaries, alienation of the people from unrepresentative governance, and diminutive development of the localities.

Of course, all of the above smack of corruption, which is a big challenge of LGs in Nigeria. The literature is replete with screaming headlines about alarming corruption in the Nigerian LG system (See, e.g., Newswatch Magazine 200I; Vanguard Newspaper 2007). They carry headlines of massive corruption and quizzing of LG functionaries by the respective anti-corruption bodies in the country. But very unfortunately, the LG corruption is the type that the World Bank (200I: xiii) has called 'grand corruption'. It does not cohabit with development.

\section{Recommendations}

These recommendations are made to promote the LG institution that the Political Bureau Report (Nigeria 1987: 120), a foremost report that the vast majority of well meaning Nigerians contributed to, called 'Local Government for development'. LG areas in the country are in dire need of real development.

Autonomy - LGs in Nigeria need adequate autonomy that can facilitate their operations and development of the localities. This should emanate from institutionalized democratic process of elections for representative LG councils as and when due. This should be in line with what obtains at the State and Federal government levels where elections are timely conducted. More will be said about democratic consolidation below.

Inkanyiso, Jnl Hum \& Soc Sci 20I I, 3(I) 
Adequate autonomy should be manifestly accorded LGs in other areas such as finance, revenue generation and expenditure, personnel administration and development matters. The literature that has largely, if not indeed entirely, agreed about poached LG autonomy will recognize adequate LG autonomy when it is granted by higher level governments. Adequate LG autonomy will forestall the current alibi that LGs make with inadequate autonomy for their diminutive development impact in their areas. In this study, LG autonomy for development has been taken as an independent variable, an overriding factor.

LG Finances - Three aspects of LG revenue need representation in our recommendation here. First is that State governments should extend the rightful financial allocations to LGs as the Federal government does. State governments should also totally eliminate all forms of interference with LGs' revenue from the federation account, an interference that is well documented by many writers (e.g., Aghayere 1997; Omoruyi 1995; Ola and Tonwe 2005). LG autonomy is no doubt promoted by such policy adherence. The second aspect is that LGs must work hard to shore up their autonomy themselves through more internal revenue generation (IRG). This recommendation agrees with the recommendation of the Political Bureau Report (Nigeria 1987). The ripple effect of this recommendation could be that the citizenry would have more stake in governance. They would be more sensitive to governmental activities and developmental efforts. This increased sensitivity could also encourage the LGs to engage more in the development of the localities through enhanced transparency. All this in turn could culminate in more appreciation from the people and greater autonomy from higher level governments.

\section{Action - not verbal - institutionalization}

This recommendation dove-tails into the last one above. The concept of 'action - not verbal - institutionalization' is meant to strongly remind the LGCs in Nigeria about their developmental responsibilities to the people. This is because positive or development responsibilities are the raison d' etre for the creation of LGs. A popular slogan says "by thy fruits, ye shall be known". As at now virtually all the LGs in Nigeria try to institutionalize themselves verbally and in the media, especially in the electronic. They marginally institutionalize themselves through sparse or lean developmental impact on ground. Road works (rehabilitation or construction), pipe borne water, electricity, health care delivery, good learning environment and functional education are few and far apart in the LG areas. Hence the importance of this recommendation that LGs should do less of verbal, but more of action, institutionalization. A lot of advertisement, jingles, posters, political solidarity rallies, etc. rather than developmental activities as conceptualized in section two of this paper are carried on by the LGCs. There should rather be more developmental activities on ground at the local area, which would constitute the bastion of action institutionalization. The latter actually carries with it the verbal one in the spirit of the popular adage that "action speaks louder than voice". In deed, any developmental action for a community is known by the community concerned and hardly needs any advertisement on television for the locality to know about it. Development activities, in fact, advertise LGs to the host community as well as to other communities and persons more than LGs do electronically.

Action-institutionalization would earn the LGCs all the respect, protection and autonomy they need from the locality, the people and higher level governments. It may completely eliminate the spate of dissolution of LGCs in Nigeria. To be able to earn the above, the LGCs can hardly succeed through sycophancy or abiding by the whims and caprices of the higher level governments. Such has been the situation which has not taken LGCs far. To be sure, more developmental activities from the LGCs will, no doubt, do the trick.

\section{Need for democratic consolidation}

Nigeria needs democratic consolidation as a formidable partner with the rule of law that can help to entrench the constitutional provisions on LGs. As we have seen in this study, there are many provisions in the 1999 Constitution that are disregarded. For example, section 7 of the 1999 Constitution guaranteeing, 'The system of local government by democratically elected local government councils' has not been respected by the State and Federal governments. Such provisions, including that on the establishment of a joint State - Local government account, can have easy recognition, acceptance and utilization by the Federal and State governments if a democratic culture is in vogue in the country. In it, the political leaders or elite will be afraid or respect democratic tenets. This is because they realize that failure to do so will earn them the wrath of the electorate who can exercise the right to change their leaders. The power of the electorate is weak in a non-consolidated democracy, the type which presently operates in Nigeria as at 2007. It is the one in which the political leaders select rulers instead of the electorate electing their leaders. The strengthening and application of largely acceptable democratic culture will reduce arbitrariness. It will enhance respect for orderliness, the rule of law to the advantage of the LG system and hence its autonomy. All this is expected to have a rippling effect on the development of the locality by the LGCs to the benefit of the people.

Inkanyiso, Jnl Hum \& Soc Sci 20I I, 3(I) 


\section{Corruption, discipline and rule of law}

The great deal of corruption in Nigerian LG system should be properly handled by the appropriate institutions, including the ICPC and EFCC. The grand corruption described by the World Bank as not cohabiting with development is the intolerable type that should be excised from the LG system.

Discipline should also be emphasized. The Political Bureau Report had emphasized discipline in the polity as a necessary ingredient for development (Nigeria, 1987). Discipline helps to eliminate corruption and, of course, any LG functionary who is corrupt and infringes on the law should be dealt with according to the law. This is the symbiotic relationship between corruption, discipline and rule of law. Corruption must reduce through discipline and operation of the rule of law. These and sustainable democratic process can also eliminate the canker worm of patron/godfather politics in the LG, to the enhanced development of the localities and great autonomy of the LGs.

\section{Conclusion}

Ascertaining the extent of LG autonomy in Nigeria with a view to determining how far it has impacted on the development of the localities has been the main focus of this study. This is because the local areas are critically in need of development projects and better life from the LGs. To scientifically undertake the above purpose, this study traversed theoretical framework, conceptualizations, and discussed dominant issues in LG autonomy. These were followed by analysis of critical issues in LG autonomy and development of local areas. These issues bordered on some of the achievements of the LGs, such as roads construction, provision of health facilities, and pipe borne water. The study established that LGs have only made marginal impact in the localities.

The study took a deep look into the challenges of the LGs that might have contributed to their lean impact, and dealt with the dominant ones for space constraint. These included the structural problems which arise from domineering relationships between the LGs and the higher level governments. They have impact for dimmed autonomy of LGs. Financial and personnel matters were also considered and found to be sour points in the quest for LG autonomy in Nigeria. Other challenges to LGs' autonomy that were found out in the study are godfather notoriety and fledging democracy. Democracy, which is supposed to be due process-bound, is easily brushed aside in Nigeria, culminating in unconstitutional abrogation of LGs from time to time.

Some of the suggestions to reverse the problems of LGs for development were as follows. The shoring up of LG autonomy to an adequate level by the higher level governments, through proper intergovernmental relations and constitutionalism. The LGs themselves should work harder at their autonomy through more IGR and overt development impact in the localities, rather than verbal electronic institutionalization and autonomy laundry. Democratic consolidation and reduced corruption were also canvassed in the recommendations.

\section{References}

Adamolekun, L. 1983. Public Administration: A Nigerian and comparative perspective, London: Longman.

Aghayere V.O. 1991. Strategies for achieving increased performance in Nigerian local government: The case of Bendel state, Unpublished Ph.D. Thesis, University of Benin, Benin City.

Aghayere V.O. 1997. Dominant issues in Nigerian local government system: A contemporary focus, Benin City: Imprint Services.

Aghayere V.O. 2008. The dynamics of centre - periphery dominance in the Nigerian political system: The local government experience, 30th Inaugural lecture series, Ekpoma: Ambrose Alli University, February.

Akpotor, A.S. 1995. Local government autonomy: Implications for rural development and democracy. In A.E. Ekoko, et al. (eds). The political economy of local government reforms and transition to the third republic, Ekpoma: Department of Political Science.

Almond, Gabriel A. 1960. Introduction: A functional approach to comparative politics. In Gabriel A. Almond and James S. Coleman (eds). The politics of developing areas, Princeton: Princeton University Press.

Bauchi State of Nigeria 2004. Annual report, local government service commission, Bauchi State: Bauchi Government Printer.

Chaturvedi, A.K. 2006. Dictionary of political science, New Delhi: Academic (India) Publishers.

Easton, David 1965. A Framework for political analysis, Englewood Cliffs, New Jersey: Printice Hall.

Edo State of Nigeria 2005. Annual report 2005, Local government service commission, Ist January to 3 Ist December, Benin City: Giftprints Associates.

Erero, J. 1998. Intergovernmental relations of the local level since 1988 civil service reforms. The Quarterly Journal of Administration, Vol. XXIX, Nos. I \& 2, Oct./Jan., 1997/I998, pp.264-273.

Gboyega, Alex 1993. Local government reform in Nigeria. In Philip Mawhood (ed.), Local government in the third world: Experience of decentralization in tropical Africa, South Africa: Africa Institute of South Africa.

Ibeanu, Oke2006. Conceptualising peace. In S.G. Best, Introduction to peace and conflict studies in West Africa, Ibadan: Spectrum Books.

Idahosa, S.A. and A.O. Igbineweka 1996. Preservation of federalism: A lesson for Nigeria, Benin Journal of Social Sciences, Vol.5, Nos. I \& 2, Nov., I-II. 
Ikelegbe, Augustine 2005. The local government system and grassroots development in Nigeria: Issues, problems and challenges. In A.G. Onokerhoraye and G.E.D. Omuta (eds) Perspectives on development: A book in honour of Pius O. Sada, Benin City: Centre for Population and Environment Development.

Imhanlahimhin, J. E. 2000. Development administration in the less developed countries, Lagos: Amfitop Books.

Imhanlahimi, J.E. and M.O. Ikeanyibe 2009. A review of Nigerian government's efforts to enhance L.G. autonomy. African Administrative Studies, No.72,Morocco,79-106.

Mabogunje, Akin. 1980. The development process: A spatial perspective, London: Hutchinson University.

Mackeazie, W.J.M. 1967. Politics and social sciences, London: Macmillan.

Mawhood, Philip C. 1993. (ed) Local government in the third world: Experience of decentralization in tropical Africa, South Africa: Africa Institute of South Africa.

Mukoro, A. 200I. Local government and rural development in Nigeria. Ife Social Sciences Review, Vol. I9, No. I, June, I55-I62.

Nehuchukwe, F.E. 2003. Local government finances in Nigeria: Issues in the generation, utilization, accountability and service delivery, Unpublished Postgraduate Seminar Paper, University of Benin, Benin City.

Newswatch Magazine 200I. Looting of local governments, Newswatch Magazine, June 25.

Nigeria, Federal Republic 1976. Guidelines for local government reform, Kaduna: Government Printer.

Nigeria, 1987. Report of the political bureau, Abuja; Directorate for Social Mobilization.

Nigeria, 1999a. 1999 Constitution of the Federal Republic of Nigeria, Abuja: Federal Government Printer.

Nigeria, 1999b. Annual abstracts of statistics 1999 edition, Abuja: Federal Office of Statistics.

Nigeria, 200I. Central Bank of Nigeria: Annual report and statement of accounts for the year ended 3 Ist December, $200 \mathrm{I}$.

Nigeria, 2003. Central Bank of Nigeria: Annual report and statement of accounts for the year ended 3 Ist December, 2003.

Nigeria, 2006. Central Bank of Nigeria: Annual report and statement of accounts for the year ended 3 Ist December, 2006.

Nigeria, 2007. Official gazette, no. 24, vol. 94, 15 May, Lagos: Federal Government Printer.

Offiong, O. J. 1996. Systems theory and structural functionalism in political analysis. In A.O. Oronsaye (ed). Nigerian government and politics, Benin City: Petersam Publishers.

Ola, R. F. 1984. Local administration in Nigeria, London: Kegan Paul International.

Ola, R.F. and D.A. Tonwe 2005. Local administration and local government in Nigeria, Apapa-Lagos: Amfitop Books.

Ola, R.O.F. 1996. Local democracy: The concept to embrace in the new Nigeria of the 2 I st century, Benin City: University of Benin Inaugural Lecture Series 42.

Omoruyi, Omo 1995. Local government reforms and implications for grassroots democracy in Nigeria. In A.E. Ekoko, et al. (eds). The political economy of local government reforms....

Stolpher, W.F. 1966. Planning without facts: Lessons in resource allocation, Cambridge, Mass.: Harvard University Press.

Vanguard Newspaper 2007. Independent corrupt practices commission quizzes some local government chairmen, September 19.

Wheare, K.C. 1946. Federal government, New York: Oxford University Press.

Wilson, W. 1887. The study of administration. cited in J.M. Shafritz and A.C. Hyde (eds). Classics of public administration, Illinois: Moore Publishing Coy.

World Bank 200I. Tanzania at the turn of the century: From reform to sustainable growth and poverty reduction, Washington, D.C: The World Bank.

Yesufu, T.M. 1996. The Nigerian economy: Growth without development, Benin City: Benin Social Science Series for Africa.

Yobe State of Nigeria 2003. Annual report of the local government service commission, Yobe Government Printer. 